\title{
LASP1/MLL Fusion Protein
}

National Cancer Institute

\section{Source}

National Cancer Institute. LASP1/MLL Fusion Protein. NCI Thesaurus. Code C99579.

A fusion protein encoded by the LASP1/MLL fusion gene. This protein is comprised of the $\mathrm{N}$-terminal half of the LIM and SH3 domain protein 1, including the LIM and actin-binding domains, fused with the C-terminal zinc finger and SET domains of the histone-lysine Nmethyltransferase MLL protein. 